\title{
Memórias e identidades em narrativas orais de mulheres domésticas negras: análise de histórias de vida
}

MEMORIES AND IDENTITIES IN ORAL NARRATIVES OF BLACK MAIDS: AN ANALYSIS OF LIFE HISTORIES

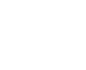

\section{Vilma Lemos}

Doutora em Linguística Aplicada e Estudos da Linguagem pela Pontifícia Universidade Católica de São Paulo. Pesquisadora-colaboradora do Memórias do ABC, USCS. lemosvilma406@gmail.com

\section{Resumo}

Este artigo analisa o discurso oral narrado de cinco mulheres negras domésticas, gravado em forma de entrevistas, considerando a constituição de sua identidade, as relações de trabalho e o preconceito racial. A análise dos depoimentos ancora-se nos pressupostos da Análise do Discurso e se conduz tendo por base a História Oral e de vida e a memória.

Palavras-chave: Domésticas negras. Identidades. Narrativas orais

\begin{abstract}
This article analyzes the oral discourse of five black maids, recorded in the form of interviews, considering the constitution of their identity, labor relations and racial prejudice. The analysis of the testimonies is built on the principles of the discourse analysis and is conducted based on oral and life history and memory.
\end{abstract}

Keywords: Black maids. Identities. Oral narratives. 


\section{A cena da enunciação}

O ponto de partida deste artigo foi o discurso - entendido como o lugar da constituição da subjetividade - de cinco domésticas negras gravado em forma de entrevistas, segundo a técnica da História Oral, um modo de aproximação desses sujeitos pelo viés da memória, que rememoraram e narraram suas trajetórias.

Considerando a validade da História Oral e sua legitimidade no quadro dos historiadores de formação clássica, informa Alberti (2005, p. 13), a História Oral

é legítima como fonte, porque não induz a mais erros que outras fontes documentais e históricas [...] Na história oral a versão representa a ideologia em movimento e tem a particularidade, não necessariamente negativa, de "reconstruir" e totalizar, reinterpretar o fato.

Os depoimentos gravados em vídeo em 2014 duraram cerca de 40 minutos e foram armazenados em um banco de dados hipermídia, assim como as transcrições e cessão de direitos de voz e imagem. A entrevista, conforme propõe a História Oral, propicia, pela escuta sensível, a valorização dos sujeitos. Note-se como Thompson ( 2006 2006, p. 20) concebe a História Oral:

na minha opinião é uma abordagem ampla, é a interpretação da história e das sociedades e culturas em processo de transformação, por intermédio da escuta às pessoas e do registro das histórias de suas vidas.

Objetivou-se, com este artigo, valorizar e dar visibilidade às histórias de vida dessas mulheres, analisar a atividade de doméstica nas relações de trabalho e a constituição de seu "eu" pelo discurso. Os referenciais da análise amparam-se na Análise do Discurso para descrever o que fazem as pessoas ao usarem a linguagem, observando os aspectos linguísticos nessa atividade, em contexto social. Ressalta-se o que diz Orlandi (2001, p. 17) sobre discurso e linguagem:

O discurso é um objeto histórico-social, cuja especificidade está em sua materialidade, que é linguística. [...] Na perspectiva da análise de discurso, entretanto, tomar a palavra é um ato social com todas as suas implicações: conflitos, reconhecimentos, relações de poder, constituição de identidades etc.

A linguagem, assim, não é vista apenas como suporte do pensamento, nem somente como instrumento de comunicação. 
A autora adverte que a Análise do Discurso

não é um método de interpretação, não atribui nenhum sentido ao texto. O que ela faz é problematizar a relação com o texto, procurando apenas explicitar os processos de significação que nele estão configurados, os mecanismos de produção de sentidos que estão funcionando. (Ibid., p. 117).

Fique claro, neste artigo, que se entende o discurso para além da frase, orientado em função de uma finalidade, compreendido como uma forma de ação sobre o outro, marcada pelo binômio "eu-você" na interatividade (dialogismo), de forma contextualizada (MAINGUENEAU, 2001, p. 52-55). Como se assume aqui que a narrativa é um caso particular de discurso, a forma de analisar as narrativas das depoentes seguirá também a forma de Análise do Discurso.

O referencial de análise dialogará com duas correntes porque são complementares nas lacunas de cada uma: as tendências de análise de discurso de linha francesa de Maingueneau (2001) e a análise crítica do discurso de Fairclough (2001).

Esta postura de análise encontra abono no pensamento de Demo (2009, p. 53), para quem é uma impossibilidade a uma teoria apreender tudo.

Sendo teoria uma construção mental simplificada/idealizada e, por isso mesmo, naturalmente reducionista $[\ldots]$ sem falar em sua face multicultural [...], não se consegue, por mais que o queira ou prometa, abarcar tudo e oferecer a última explicação.

Também a memória é fundadora nesta proposta de trabalhar com história de vida, porque as depoentes narraram suas histórias, rememorando, a partir do presente, os acontecimentos de suas vidas. Destaque-se a importância desse aspecto, segundo Worcman e Pereira (2006, p. 203):

A narrativa muda também de acordo com a fase da vida. Por isso dizemos que a história de vida não conta apenas o "passado" de uma pessoa, mas revela muito sobre seu presente e indica como ela vislumbra seu futuro. Aí reside, em grande parte, o impacto das histórias.

E como a memória é importante para o ato de relembrar e se atrela também à identidade, atente-se para o que diz Pollak (1992, p. 204): 
A memória é um elemento constituinte do sentimento de identidade, tanto individual como coletiva, na medida em que ela é também um fator extremamente importante do sentimento de continuidade e de coerência de uma pessoa ou de um grupo em sua reconstrução de si.

Como os depoimentos são influenciados pelo momento presente das depoentes, devem ser entendidos como reinterpretações do passado, porque são movidos pela memória, aqui considerada não como um fenômeno individual, mas como uma construção social. Halbwachs (1990, p. 51) afirma que o pensamento individual sustenta-se no coletivo, cada memória individual é um ponto de vista sobre a memória coletiva. Estas depoentes, portanto, contam suas histórias individuais, mas refletem um contexto coletivo na história de sua atividade de domésticas no Brasil.

Le Goff (1984, p. 12) destaca a importância do comportamento narrativo e sua função social, quando os sujeitos comunicam uma informação na ausência do acontecimento ou objeto narrado e isso passa pela intervenção da linguagem, produto da sociedade e essencial no armazenamento e reprodução da memória.

Durante as entrevistas, o processo é dialógico (BAKHTIN, 1988), já que há uma audiência na relação narrador-ouvinte, ou seja, o discurso narrativo é feito para outro. Nessas entrevistas, o depoente comprime sua história de vida, de forma subjetiva, reconstruindo suas lembranças pela memória. Portelli (1985 apud THOMPSON, 2002, p. 183) afirma:

Os fatos de que as pessoas se lembram (e se esquecem) são, eles mesmos, a substância de que é feita a história. [...] A subjetividade é do interesse da história, tanto quanto os "fatos" mais visíveis. O que o informante acredita é, na verdade, um fato (isto é, o fato de que ele acredita nisso) tanto quanto o que "realmente" aconteceu.

\section{Narrativas e discurso na construção de identidades}

concebe-se aqui linguagem como discurso pela ação humana em relação a um contexto interacional específico (no caso, a entrevista), o que implica reconhecer um outro além do sujeito em foco. Têm-se, portanto, os sujeitos - entrevistado e entrevistador - em um contexto de produção (entrevista de história de vida). Isso implica afirmar que as marcas identitárias inscrevem-se no discurso de ambos durante a interlocução e que a alteridade e a situacionalidade são marcas do discurso levadas em consideração neste artigo.

Para Fairclough (2001, p. 22), “os discursos não apenas refletem ou representam entidades e relações sociais, eles as constroem ou as 'constituem'". 
Considera-se, portanto, a entrevista como um ato discursivo e as narrativas como processos discursivos na interação com o outro, que levam à compreensão da vida social e à construção de identidades sociais. Ou, como afirma Hall (1999, p. 13), tratando da discussão das identidades, ou, melhor dizendo, identificações:

O sujeito assume identidades diferentes em diferentes momentos, identidades que não são unificadas ao redor de um "eu" coerente. Dentro de nós há identidades contraditórias, empurrando em diferentes direções, de tal modo que nossas identificações estão sendo continuamente deslocadas. Se sentimos que temos uma identidade unificada desde o nascimento até a morte é apenas porque construímos uma cômoda estória sobre nós mesmos ou uma confortadora "narrativa do eu". A identidade plenamente unificada, completa, segura e coerente é uma fantasia.

O que se pretende aqui, portanto, é analisar como as identidades destas mulheres são constituídas por elas por meio de suas narrativas.

Orientam a análise das narrativas as tendências francesas da Análise do Discurso (MAINGUENEAU, 2000), na observância de como os sujeitos se inscrevem em seus discursos ao relatar suas histórias de vida (o que se fala, com que finalidade e de que lugar social se fala). Como a Análise do Discurso é interpretativa, não há passos ou procedimentos técnicos mecânicos para análise das narrativas. Além dessa visão teórica presente na análise, é preciso considerar o posicionamento da análise crítica do discurso (ACD) e o conceito de ethos como "imagem que o locutor constrói em seu discurso para exercer uma influência sobre seu alocutório" (CHARAUDEAU; MAINGUENEAU, 2004, p. 220), bem como a noção de contexto com base nos níveis semântico, lexicogramatical, fonológico da linguagem e situacional, social e cultural.

Como a ACD também concorda que "não há procedimento fixo para se fazer análise de discurso" (FAIRCLOUGH, 2001, p. 275), os pressupostos das duas vertentes estarão subjacentes ao olhar atento da analista.

Para Fairclough (2001, p. 209), o conceito de ethos une tanto as características do discurso quanto do comportamento em geral, levando à "versão particular do eu". Nesse aspecto, ao tratar de discurso, o autor vê a linguagem como "forma de prática social e não como atividade puramente individual ou reflexo de variáveis situacionais” (Ibid., p. 90).

Aqui não se está apregoando que a sociedade seja apenas discursiva, conforme esclarece Iñiguez (2004, p. 13):

Embora muitos aspectos e problemas da sociedade sejam discursivos ou possam ser estudados por várias formas da análise do discurso, isso não quer dizer que a sociedade é apenas discursiva, 
como demonstram a pobreza, a fome, as doenças, a violência contra as mulheres, o racismo e muitos outros problemas sociais cruciais. No entanto, nosso pensamento, nossa interpretação e nossa comunicação sobre esses problemas são, na maior parte das vezes, expressos ou reproduzidos através do texto ou da fala e muitas vezes constituídos discursivamente.

Fique claro, portanto, que a linguagem não é puramente representacional, mas é atividade, com ela é possível fazer coisas, conforme afirma Gracia (apud IÑIGUEZ, 2004, p. 40), referindo-se a C. Taylor e seu estudo da identidade ou do self:

Para Taylor, nossa identidade está fundamentalmente determinada pela linguagem que utilizamos para referir-nos a nós mesmos e para forjar nosso "autoconceito". Não existe uma realidade subjacente, um "eu" profundo e pessoal, suscetível de ser descrito de várias maneiras, recorrendo a vocabulários distintos e a distintas expressões linguísticas: o que sim existe é o próprio vocabulário que utilizo para me descrever a mim mesmo e as expressões linguísticas às quais recorro para fazê-lo são constituintes e constitutivas de minha forma de ser; elas não explicitam ou explicam minha maneira de ser, pelo contrário, a conformam.

Tanto para a História Oral quanto para a Análise do Discurso (AD), a interdisciplaridade é produtiva para compreender a multiplicidade de sentidos nas interações humanas, destacando a subjetividade manifesta nas narrativas orais dos indivíduos/sujeitos sociais e sua valorização, bem como suas concepções de mundo, sua cultura. Nesse sentido, os estudos de comunicação são enriquecidos quando se amplia o olhar crítico sobre os discursos orais desses sujeitos e sua forma de comunicação da cultura e dos sentidos que constroem em determinados contextos, considerando os interlocutores. Como afirma Pinto (1999, p. 22):

O analista de discurso é uma espécie de detetive sociocultural. Sua prática é primordialmente a de procurar e interpretar vestígios que permitem a contextualização em três níveis: o contexto situacional imediato, o contexto institucional e o contexto sociocultural mais amplo, no interior dos quais se deu o evento comunicacional.

Por não se tratar de interpretação semântica de conteúdos, o autor destaca que importa para a AD "explicar os modos de dizer (uso comunicacional da linguagem e de outras semióticas) exibidos pelos textos", aos quais acrescenta os modos de mostrar, modos de interagir e modos de seduzir (Ibid., p. 23).

Considerar que os textos não são transparentes e que os sujeitos não são os únicos responsáveis por suas falas também é fundamental para a AD. 
Todo texto é híbrido ou heterogêneo quanto à sua enunciação, no sentido de que ele é sempre um tecido de "vozes" ou citações, cuja autoria fica marcada ou não, vindas de outros textos preexistentes, contemporâneos ou do passado. (Ibid., p. 27).

Portanto, para os estudos de comunicação e da cultura pelo viés da AD e da História Oral os sujeitos, sua valorização e constituição, a importância do contexto e a heterogeneidade dos textos, acrescidos do lugar social de onde fala esse sujeito, para quem fala e o modo como fala, são elementos centrais que enriquecem as pesquisas e seus resultados.

Como afirma Iñiguez $(2004$, p. 53), "o que devemos destacar com relação à AD não é sua importância como método e sim o fato de que ela é uma perspectiva da qual podemos analisar os processos sociais".

A confluência e complementaridade de metodologias e perspectivas de análise entre História Oral e análise de discurso resultam positivas para a comunicação porque possibilitam uma análise mais ampla na compreensão da vida social, das relações de comunicação e cultura que os narradores constroem durante suas narrativas orais.

Para compreender o universo em que se constituem os sujeitos que contaram suas histórias de vida, segue-se o perfil das cinco depoentes entrevistadas.

\section{Perfil das depoentes}

Foram entrevistadas cinco mulheres negras, que trabalham como domésticas, com idades entre 35 e 52 anos. Todas têm origem humilde, escolarização incompleta e precárias condições familiares. Provêm da zona rural de Minas Gerais, Bahia, Piauí, sendo apenas uma delas do interior de São Paulo. Todas trabalham na região do ABC Paulista.

Este perfil não destoa das pesquisas do DIEESE (2013), cujas estatísticas ainda apontam para a exclusão, mesmo após 126 anos da promulgação da Lei Áurea (13 de maio de 1888), que extinguia a escravidão no país: de 2004 a 2011, elevou-se de $56 \%$ para $61 \%$ o número de domésticas negras. , ao passo que houve redução de $43,1 \%$ para $39 \%$ entre domésticas não negras. A região Sudeste apresentou o maior número de mulheres negras no trabalho doméstico: de 52,3\% em 2004 para 57,2\% em 2011. Entre as mais jovens, por causa do maior acesso à escolarização, este número tem diminuído (DIEESE, 2013, p. 6).

As depoentes aqui enfocadas trabalham como diaristas, trabalhando, muitas vezes, de domingo a domingo, sem os benefícios de empregados assalariados. As exceções relacionam-se a Raquel, 35, que tendo trabalhado em aproximadamente 10 casas de família desde os 9 anos, atualmente trabalha como camareira de hotel, com registro na 
carteira de trabalho, e Angelina (43), que alternou trabalho como doméstica e em fábrica, prevalecendo o trabalho doméstico, depois de 8 anos em fábrica.

A mineira Maria Aparecida (41) reflete também o mesmo quadro familiar: trabalhou na roça de café com 9 anos e é de família numerosa (9 irmãos).

Luzia é uma depoente franzina, com história de vida trágica: desde seus 7 anos foi induzida a beber pinga pelo pai, trabalhador rural, cuja vida errante levou a família de 8 filhos a ser pedintes quando vieram para São Caetano do Sul. Ficou 4 anos na primeira série e, como repetia sempre, o pai resolveu tirá-la da escola.

Em relação aos estudos, a exceção é Marisa Mota (52), que, tendo interrompido os estudos do Ensino Fundamental duas vezes, atualmente está terminando o Ensino Médio no SESI.

No contexto em que se delineiam as histórias de vida dessas trabalhadoras domésticas, destacaram-se a origem humilde, precárias condições de vida dos pais, oriundas do trabalho braçal na roça, pouca ou incompleta escolarização e baixa qualificação profissional, o que mantém este quadro perverso entre essas mulheres. Acrescentam-se ao quadro as relações afetivas esgarçadas na constituição das suas próprias famílias - nem sempre pelo casamento civil -, os muitos relatos de separações e a vulnerabilidade, em alguns casos, resultando em alcoolismo, depressão e tentativas de suicídio.

Em resumo, considerando a subjetividade das depoentes aqui enfocadas e seus discursos, suas memórias (e mesmo os esquecimentos e/ou silêncios), a análise de suas narrativas terá como pressupostos o conceito de linguagem como forma de ação e constituição do "eu". O contexto de trabalhadoras domésticas e das relações de trabalho, bem como o preconceito racial também serão analisados.

\section{O discurso em ação: a constituição do "eu"}

Observar-se-á, neste tópico, como as depoentes vão constituindo, pelo discurso, seu ethos e, consequentemente, suas identidades.

Angelina já havia trabalhado como doméstica em Teresina (PI), por 6 meses, aos 22 anos. Com 28 anos foi para São Paulo, onde já estava uma irmã, trabalhar em casa de família. Ao engravidar, viu-se sozinha para resolver seus problemas. Observam-se os recortes de sua narrativa nesta circunstância.

Eu já morava sozinha, eu pagava aluguel, morava sozinha [...] ele [filho] era pequeno, tinha dificuldades com quem deixar, eu era sozinha. 
A reiteração da palavra sozinha enfatiza seu desamparo, fato que culminará, mais à frente em seu discurso, na construção valorosa de si.

Falando do pai do filho, reitera a consciência de ser sozinha e ter de resolver por si mesma os problemas: "Não participou de nada, porque eu praticamente era sozinha, sustentava sozinha."

O uso enfático do eu/meu/minha, no contexto de adversidades que relata, constrói para o interlocutor a imagem da mulher batalhadora nos fragmentos do discurso narrativo a seguir: "Eu construí a minha casa. Fiz a minha casa embaixo."

Quando conheceu seu atual companheiro, seu filho tinha dois anos: "A gente foi morar junto, porque a casa era minha, então, ele foi morar comigo." Novamente observa-se a ênfase de pronomes de $1^{\text {a }}$ pessoa: minha, comigo, valorizando sua casa como conquista pessoal.

Sua autoimagem de mulher de coragem, que vence batalhas, concretiza-se recorrendo ao discurso citado de terceiros, quando afirma:

Eu era sozinha, como eu falei, né? Fui uma batalhadora, muita gente admira como eu fui uma mulher de coragem, tive meu filho sozinha, consegui construir uma casa sozinha.

A repetição enfática de sozinha foi recorrente em sua narrativa, constituindo para o interlocutor sua identidade de vencedora por si mesma. Ressalta-se que não se pretende diminuir o valor da depoente, mas analisar como a seleção lexical e a reiteração foram usadas na constituição do "eu" para o outro.

Raquel é outra depoente, oriunda de Minas Gerais, cujos pais trabalhavam no campo. Quando tinha cinco anos, os pais vieram para Santo André em busca de emprego. Aos nove anos, foi trabalhar como doméstica. Casou-se duas vezes e teve sete filhos, três deles falecidos. Hoje é camareira de hotel.

Destaca-se no discurso de Raquel o "esquecimento" de fatos da infância, embora ela narre alguns deles. Como se sabe, tanto o silêncio quanto o esquecimento podem estar relacionados a fatos traumáticos que a depoente prefere não lembrar (BOSI, 2003, p. 18). Com a separação dos pais, ela ficou morando com a tia, irmã do pai, por dez anos: "Eu trabalhei muito e não tive essa infância de brincar não, era só trabalho."

Quando solicitado para falar das lembranças de aniversário e Natal, ela respondeu que nunca houve festa ou troca de presentes e que não se lembra desse período da infância:

Ah, isso aí não lembro não, amiga! Misericórdia! (risos). [...] Se você perguntar dos 20 anos para cá, eu lembro, quando eu era criança, não. 
No entanto, resgata um episódio da memória de quando já estava morando com a tia e a exclusão a que era relegada por essa tia: "Às vezes a minha tia viajava, eu ficava trancada. Ela ia para... saía com as filhas dela... Essa fase minha eu não lembro não.”

Ela também se constitui como trabalhadora com muitas habilidades.

Agora eu sou camareira, mas sempre fiz de tudo um pouco. Se falar "vamos fazer", eu sei fazer, mas, assim, é uma coisa boa que não é valorizada por todas, né?

O autoelogio em "eu sei fazer" funciona como construção positiva de si para o interlocutor, mesmo opondo, logo a seguir, uma construção iniciada por "mas" (adversativa), introduzindo uma espécie de denúncia do não reconhecimento do trabalho de limpeza que realiza e apresentando-se como argumentadora-crítica nas relações de trabalho em sua profissão.

Raquel também disse que sofreu violência doméstica dos dois maridos, que tinham ciúmes dela, por isso se separou de ambos. As cenas de violência ao longo de sua história de vida, nos seus relatos, foram marcantes, começando pela tia, que tinha três filhos, provavelmente a razão do "esquecimento" inicial quando the foi solicitado falar da infância.

Eu só via batendo em mim, então, eu sou uma das primeiras que tinha de acordar de manhã, cinco horas, para poder fazer o café da manhã para os filhos tomarem antes de eu ir para a escola. Muitas vezes não dava nem tempo de ir porque eu não tinha feito todos os afazeres da casa. Vamos supor, se eu quebrar um copo, já é motivo de você apanhar.

É interessante observar as oscilações do tempo verbal (sou, tinha, dava, tinha feito, se eu quebrar) nas suas recordações. Mesmo falando de fatos passados, ela atualiza o discurso no presente - o que parece contribuir para reviver o acontecido de maus tratos - alternando com o tempo passado. Se se considera apenas a deficiência de escolarização, pode-se dizer que a falha é comum. Também é provável que o emprego do tempo verbal presente colabore para dar mais realismo e ênfase ao sofrimento.

Estes aspectos do "eu" da narradora como sofredora ficam mais destacados quando relata ter cuidado sozinha dos filhos.

Quando se trata de filho [...] eu praticamente sou sozinha aqui onde eu moro agora. Quando meu filho faleceu [primeiro filho, aos 7 anos] eu já era separada. Ele [primeiro marido] nunca me deu apoio. 
Para mim, a fase difícil foi quando ele me deixou com meus filhos pequenos. Aí foi complicado!

Apesar da vida cheia de percalços, sobressai-se também a imagem de mulher vitoriosa na constituição de sua autoimagem (vitória muito grande).

Alegria foi ter chegado onde eu cheguei para criar meus filhos. Então, para mim, é uma vitória muito grande, então isso basta não há dinheiro que pague.

A depoente baiana Marisa (44 anos) veio para Santo André com 14 anos, trazida pela irmã, para trabalhar como doméstica. Nesse primeiro emprego, trabalhava de domingo a domingo:

Assim, eu dormia no serviço, agradeço muito a mim, primeiro a meu esforço, fui pegando conhecimento com as amigas e aí conheci o SESI, aí comecei a estudar no SESI. Só que na época eu conheci meu marido, comecei a namorar, eu mais namorava do que estudava.

Na construção de sua identidade, tem plena consciência de seu valor, pelo esforço próprio, o que a faz constituir-se para o interlocutor como valorosa: "Agradeço muito a mim, primeiro a meu esforço." Esta imagem de si é reiterada mais à frente, quando fala da vida de casada, do retorno aos estudos: "Corria muito, nunca parei, as minhas tias falam, nossa, que eu tenho uma força assim absurda de vontade de conseguir as coisas." Note-se o caráter enfático do adjetivo absurdo e sua importância no contexto de autovalorização.

A honestidade é outro traço distintivo no discurso da depoente, atrelado ao orgulho da profissão que exerce.

Tem gente que tem vergonha de falar que é doméstica hoje... Eu conheço gente que vai comprar alguma coisa e fala assim: “Qual é sua profissão?”, [e] ela não fala que é doméstica. Eu tenho orgulho de falar que eu estou fazendo uma coisa honestamente, não estou roubando, e, assim, gosto do que eu faço.

A mineira Maria Aparecida constrói sua imagem como trabalhadora multitarefa, embora tenha passado uma fase difícil em que entrou em depressão. Afirmou que "a agulha de crochê e a linha" a curaram. Aprendeu a fazer crochê sozinha, lendo revistas. Também diz que aprendeu a cozinhar e lavar com revista, porque "sempre fui curiosa". Acumulou inúmeras atividades com a função de mãe e pai dos filhos: faxina, limpeza em pizzaria, costura. Ainda quer fazer curso de pedreiro. "Meu sonho é fazer um curso de pedreiro, mas não estou tendo tempo." 
Esta imagem de incansável trabalhadora em busca de suas conquistas se concretiza na fala a seguir:

Eu trabalho de domingo a domingo. Eu nunca tive lazer. [...] Para mim, nada é impossível, tudo você pode, desde que você tenha coragem. Seja digno que importa. Se você é rico ou pobre não importa, se você for honesto, você vai longe.

Das cinco domésticas entrevistadas, Luzia é a de vida mais frágil, que não consegue escapar do apelo do álcool, mesmo já tendo procurado ajuda na AA. Eis como ela se define: "Eu sei muito pouco [...] nunca mais eu consegui estudar." Mesmo sabendo pouco, ela diz que as patroas gostam muito dela. Atualmente, alterna a limpeza em cinco casas em uma semana e na outra, em três. Sua autoimagem negativa não parece corresponder ao real, já que dá conta do trabalho em tantas casas.

\section{As relações de trabalho na vida das domésticas}

Na avaliação de Raquel, há patroas boas e outras nem tanto. Relata que, certa vez, depois de exaustiva faxina, uma patroa lhe deu miojo para comer, sendo que nem em sua própria casa ela comia isso.

Eu trabalhei com uma que me dava miojo, eu não como miojo, não tem quem me faça eu comer miojo. Então, eu deixava lá o miojinho.

A indignação pelo desrespeito a ela fica mais evidente após as negativas (não) quando a narradora usa do diminutivo para marcar ironia e não afetividade: "miojinho".

Raquel ainda reitera sua indignação com interjeições ("Misericórdia!","Ah!" e a ênfase na voz, marcada na transcrição pelas exclamações).

Não, era só para mim.[...] Mas você trabalha o dia todo, que faxina não é fácil, e você ficar se sustentando por miojo? Misericórdia! Né? Ah! Não aguento, ninguém aguenta!

Angelina, outra depoente, relata que quando o filho teve leucemia, nenhuma patroa a ajudou e, como não tinha carteira de trabalho assinada, não tinha direitos. Nota-se a consciência crítica dela em relação aos direitos trabalhistas que lhe eram negados na situação de trabalhadora sem registro. 
Eu trabalhava em casa de família sem registro e as minhas patroas... ninguém me ajudou, entendeu? Ninguém teve coragem de dizer assim "Você está precisando de uma caixa de leite? Você está precisando de dinheiro?"

Nos seis meses que trabalhou em casa de família em Teresina (PI), a experiência foi boa na sua avaliação, se comparada, mais tarde, à experiência com patroas em São Paulo, quando avalia o grau de exigência de limpeza das patroas de "frescura".

Não tinha aquela exigência de estar limpando janela [...] azulejo toda vez que for, toda semana [...] não tinha essa frescura de ficar tendo de limpar janela, tendo que subir em escada para limpar azulejo, a gente saía para passear nos final de semana.

Está implícita aí a crítica às casas em que trabalhou em São Paulo, confirmada em outro trecho:

Tive patroas ruins que, inclusive, eu trabalhei com uma aqui no Campestre [bairro de Santo André] que a "bicha" era bem... Nossa! A "bicha” era ruim, viu?

Destaca-se a seleção lexical "bicha" que utiliza para referir-se à patroa, no sentido provável de má, conforme reitera adiante com o adjetivo "ruim" e explica a diferença entre sua primeira experiência como doméstica em Teresina e em São Paulo.

Não sei se era porque eu também já estava começando a trabalhar em casa de família - foi quando eu cheguei do "Norte" - eu não tinha muita experiência. Porque a experiência do "Norte" é uma coisa e a daqui é outra! [...] Eu acho que o de lá do "Norte" é mais fácil do que o daqui.

Essa fala esclarece o implícito em relação às exigências das patroas de São Paulo, vistas como "frescuras".

Apesar de algumas experiências ruins, Angelina afirma gostar do trabalho de doméstica, embora, atualmente, só trabalhe em uma casa, uma vez por semana.

Eu gosto de trabalhar como doméstica, quando a gente encontra uma pessoa boa, sabe, uma patroa boa que... entende, assim, sabe, que a gente faz o serviço e dá valor, valoriza o seu serviço [...]. É muito bom porque dá mais motivação para gente trabalhar. 
$\mathrm{Na}$ fala que se segue, ela parece refletir e justificar a reclamação de algumas patroas sobre sua lentidão no serviço. Acrescente-se a isso também a doença do filho.

Eu ando meio, assim, parece que eu fiquei "marrenta", mais lerda, às vezes não tenho vontade de fazer as coisas, estou tomando remédio, preciso tomar remédio para ver se consigo, é... fazer as coisas, às vezes até na minha casa.

E ela conclui, analisando suas circunstâncias:

Eu trabalho porque eu acho bom trabalhar, porque é uma terapia, entendeu? É uma terapia, eu até distraio minha cabeça. Quando eu estou trabalhando, eu não estou pensando muita coisa, entendeu?

Luzia relata que uma patroa the diz sempre que "se você for me deixar um dia, pelo amor de Deus, você deixa outras casas, menos eu." Esses tipos de comentários deixam Luzia muito feliz, elevando sua autoestima, razão pela qual diz que as patroas em geral são boas e que não gostou de poucas.

Marisa conta que teve um patrão que foi como um pai para ela quando foi despejada com a família da casa onde morava. Ele a ajudou a comprar o apartamento, emprestando parte do dinheiro, que ela devolveu em 3 anos, período em que não recebeu salário para saldar a dívida. No entanto, teve uma experiência extremamente marcante em uma casa anterior, o que resultou em sua demissão.

A filha dela tava com o namorado, e tinha um cachorrinho que tinha mania de fazer xixi na fruta, sabe? Na fruteira. Aí ele fez cocô na hora de... que o pessoal tava almoçando, assim, só ela e o namorado dela, né? [...] Ela mandou catar o cocô, eu falei que não ia catar naquela hora porque eu estava ocupada. Ela falou: "Se você não quer catar com a mão, cata com a boca". Eu respondi "Cata você com a boca, porque eu nunca catei cocô com a boca, se você está acostumada..." Aí me mandaram embora por essa causa.

E arremata a lembrança de forma irônica: "O dinheiro que eu recebi dela, no tempo que eu trabalhei, deu para eu comprar um moletom, uma calça e uma blusa de moletom."

A imagem do trabalho como servidão e do trabalhador como escravo é um desabafo de Marisa. Essa fala é sua análise em relação aos primeiros trabalhos de doméstica, segundo ela, porque não conhecia nada.

$68 \frac{\text { Comunicação \& Inovação, PPGCOM/USCS }}{\text { v. 16, n. } 30 \text { (55-74) jan-abr } 2015}$ 
A gente é meio que escravo, vira escravo deles. [...] Você não tem hora de acabar o serviço, você trabalha até não sei que hora. Você tem que fazer as coisas, é obrigada a fazer. Você sabe sua obrigação, né? Mas acho que tem que ter horário, né?

Maria Aparecida veio com 12 anos para São Paulo com a madrinha para trabalhar como doméstica. A noção de trabalho escravo também emerge na sua fala.

Eu trabalhava como escrava Isaura. Tinha três crianças, eu tinha de cuidar das crianças, só tinha comida para as crianças, para mim não tinha.

Na sua memória de discriminação, ela relembra:

Te deixa tão chateada que parece que ser doméstica é crime, né? Tem gente que humilha mesmo, humilha de pouquinho. Joga uma indiretinha: "Ta aqui porque não estudou, se tivesse estudado..."

\section{O preconceito racial}

A depoente Angelina considera-se afrodescendente e se identifica como parda. Informou que sua bisavó materna era índia e a mãe é morena, "cabocla mesmo, de cabelo liso", e o pai, negro. Observa-se a hesitação ao falar do pai e o eufemismo em ação no em discurso ao tratar deste aspecto.

Nós já saímos assim porque meu pai era negro, meu pai era negro mesmo, do cabelo mais... mais crespo, que não era ruim, era mais crespo.

A hesitação dela ao falar do cabelo e a explicação de que "não era ruim" prendem-se a um estereótipo social de discriminação em que cabelo de afrodescendentes é ruim por não ser liso. Ressalva que a irmã mais velha é branca de olhos claros e que seu irmão também é branco, justificando que a avó paterna também era branca, mas o avô era negro.

Agora já tem eu que sou a mais moreninha, a mais "nega" mesmo sou eu. Porque as outras são mais claras, morena clara, e eu sou a que saiu mais escurinha (risos).

As três palavras selecionadas por ela relativas à sua cor têm conotações diferentes: moreninha, suaviza "nega", palavra de maior impacto. Ela fecha seu discurso com o abrandamento semântico das palavras, usando um diminutivo - escurinha - e com o riso. 
De que lugar social fala Angelina neste discurso, privilegiando os aspectos brancos da família? Estaria o preconceito implícito em sua seleção de palavras ao falar de si? A que memória seu discurso recorre, a uma memória coletiva de um grupo excluído ao longo da história?

Apesar de todas essas nuances nas palavras dela, ela disse nunca ter sofrido preconceito racial, o que não ocorreu com Raquel, cuja visão sobre o tema é mais contundente e as vivências de preconceito também. Ela exemplifica, falando de uma vivência nas Casas Bahia.

\begin{abstract}
Vamos supor, eu estou de chinelinho. Se eu chegar, eles não dão muita atenção, por causa da cor, eu tenho quase certeza que é isso. Você coloca uma roupinha melhor, eles te tratam muito bem, porque já aconteceu isso comigo [...] Tem coisa que me mata, eu chegar em loja e ficar nego atrás de mim, eu não suporto isso. Então, eu creio que é por causa da cor, ou você vai roubar, você sabe?
\end{abstract}

O que Raquel faz aqui é uma inferência ao julgar que está sendo avaliada como ladra. E tão enfática é sua observação que não percebe o uso da expressão depreciativa nego em relação ao outro. O preconceito, aqui, parece estar colado na própria depoente.

Embora ela afirme categoricamente nunca ter sofrido preconceito racial nas casas em que trabalhou, relata, em outro momento da entrevista, um fato que a marcou muito, quando foi contratada para trabalhar com uma família de japoneses.

Fui trabalhar com japonês e me falaram: "Como você é negra, você não pode entrar pela porta da frente". [...] Dei meia volta, o marido dela estava lá. Ele falou assim: "Essa pessoa dessa cor eu não quero na minha casa." Eu sei que eu chorei muito. Eu virei as costas: "Estou indo embora, aqui eu não fico!" Foi uma das coisas que foi pior em toda minha vida, estou com 35 anos, essa foi a minha pior. Por causa da cor, né? Então, tem o racismo, não adianta ninguém falar. Tem!

Esta lembrança tão traumática provavelmente contribuiu para sua negação de ter vivenciado problemas em relação à sua cor negra em um primeiro momento. A situação enfrentada também a fez ter um preconceito em relação a famílias japonesas do qual ela não tem consciência, porque diz que não trabalha para japoneses.

Marisa também relata um episódio em que sentiu o preconceito, quando estava em uma fila, em uma expressão agressiva em relação a sua cor feita por outra pessoa que estava no local. 
Uma pessoa falou para mim assim, numa fila [...] "Nego (falou assim, meio como um palavrão), quando não faz na entrada, faz na saída". Eu senti que aquilo foi comigo, porque eu estava na fila e a moça falou: "Fique aqui desse lado", e eu não fiquei, eu fiquei, mantive na minha fila mesmo, só que depois eu fui, porque essa fila tava menor, que eu ia fazer uma outra coisa que não era naquela fila, e a pessoa falou isso comigo, e eu senti que foi comigo.

A depoente Luzia não consegue apreender o preconceito subentendido na fala de patroas, talvez por causa de sua baixa escolarização.

As pessoas nunca me falaram nada da inha cor. Tem gente até, umas patroas minhas, que são branquinhas [e dizem]: "Nossa, Luzia, eu queria ter a sua cor, eu acho tão bonito gente de cor, para mim ficar da sua cor eu tenho que viver muito lá em Santos." (risos).

$\mathrm{O}$ riso durante a lembrança mostra que entende o fato como engraçado. Ela conta que teve muitas patroas boas, que a ajudaram em momentos difíceis. Destaca-se o exemplo do período em que engravidou, afastou-se por dois meses e foi remunerada. Em um contexto de poucos direitos, ela entende como um ato de bondade. Nota-se como ela reitera a fala de que ela não quis. A depoente usa a expressão "asilo" para se referir a à creche, berçário.

Ela [a patroa] dava banho na nenê, saía [com ela], ficava cuidando pra mim fazer o serviço. [...] Ela não quis, ela não quis que eu colocava ela no "asilo".

Pereira (2011), historiadora especialista em gênero e raça, ao analisar as origens das relações de trabalho da mulher negra na pós-abolição, afirma:

O trabalho doméstico, exercido pela mulher negra, teve sua funcionalidade fortemente arraigada nas relações de favor ou compadrio, que são marcados por relações de dominação/opressão de gênero e raça, a demarcação do trabalho doméstico como sendo coisa de negra, agiu incisivamente no fortalecimento dos valores paternalistas e patriarcais, onde as relações se estabeleciam com forte apelo afetivo acrescido de uma falsa ideia de pertencimento, que perpetuavam práticas de subordinação e dependência estratificados como naturais, inerentes à mulher negra (ex-escrava).

O sentimento de gratidão de Luzia pela patroa por este ato de generosidade em relação à sua filha é grande. Claro está que, se fossem consideradas as leis trabalhistas, seria um direito. 
Já Maria Aparecida traz em suas vivências a consciência do preconceito na relação patroa-empregada, e deixa aflorar isso em seu relato:

Ela falava para mim que lá tinha que cantar e assobiar ao mesmo tempo. Quer dizer que você tem de fazer tudo de uma vez só, tipo, passando roupa, tem que estar lavando, fazendo comida. [...] Apesar de tudo isso, ela era carrasco, ela não era ruim, ela ensinava as coisas. Mas na hora do trabalho, ela achava - ainda mais preto - tem de trabalhar para valer, não é pouco não. Preto, para ela, não tinha valor. Eu me sentia humilhada, mas nunca falei nada para ela.

Duas expressões são marcantes em sua avaliação: "ainda mais preto" e "preto, para ela, não tinha valor". Mesmo afirmando que a patroa era "carrasco", paradoxalmente, afirma que ela não era ruim.

\section{Considerações finais}

As memórias narradas por estas trabalhadoras, aqui consideradas sujeitos de suas histórias pontuadas pela expressão de sua cultura, são fundamentais para a compreensão das múltiplas possibilidades de sentidos nos processos comunicacionais na vida cotidiana.

Aliar a Análise do Discurso à metodologia da História Oral nas análises das narrativas orais desses sujeitos possibilita iluminar a vida social e as relações de comunicação e cultura, ampliando sua compreensão, uma vez que toda ação, mesmo as mais cotidianas, contribui para a construção social.

As histórias de vida aqui narradas reiteram o que as estatísticas têm apontado: a exclusão histórica ainda precisa ser vencida neste universo de trabalhadoras domésticas negras. Apesar disso, essas mulheres se constituem como lutadoras e vencedoras - ethos presente no discurso de todas - ainda que a duras penas, passando por discriminação, problemas com saúde mental (depressão, tentativas de suicídio, bebida), maus tratos de companheiros ou patrões.

Não poderia ser diferente apresentarem-se como vencedoras e batalhadoras, visto que transpuseram situações adversas de penúria em relação à alimentação e moradia. Esta imagem que fazem de si mesmas é bem coerente com os discursos narrados e analisados, o que demonstra que têm uma visão crítica do estar no mundo graças a esforço pessoal, mesmo que algumas ainda morem em barracos.

Em relação ao preconceito racial, todas tiveram histórias dolorosas para contar, ainda que, eventualmente, digam não se lembrar disso.

A discriminação e o preconceito na relação patroa-empregada, algumas vezes foram velados, insinuados, ressalvam-se algumas patroas mencionadas pelas depoentes. 
Talvez invocando Santa Zita, padroeira das domésticas, os congressistas brasileiros olhassem com mais empenho para a regulamentação da PEC (Proposta de Emenda Constitucional) 478/2010 - a PEC das Domésticas, aprovada em 27 de 4 abril de 2013, Dia de Santa Zita. Isso contribuiria para melhorar as condições dessas trabalhadoras, alçando-as a patamares mais aceitáveis no mundo do trabalho. As trabalhadoras domésticas negras, maioria neste mercado, poderiam conquistar o status de cidadãs com direitos reais, deixando, efetivamente, no passado o universo da escravidão.

\section{Fontes orais ${ }^{1}$}

Angelina Maria dos Santos (43 anos)

Luzia Silveira dos Reis (52 anos)

Maria Aparecida Fernandes (41 anos)

Marisa Mota dos Santos (52 anos)

Raquel Paulina da Costa (35 anos)

\section{Referências}

ALBERTI, V. Manual de História Oral. Rio de Janeiro: FGV, 2005.

BAKHTIN, M. Marxismo e filosofia da linguagem. São Paulo: Hucitec, 1988.

BOSI, E. A substância social da memória. In: O tempo vivo da memória. São Paulo: Ateliê, 2003.

CHARAUDEAU, P.; MAINGENEAU, D. Dicionário de Análise do Discurso. Coordenação da tradução Fabiana Komesu. São Paulo: Contexto, 2004.

DEMO, P. Aprendizagens e novas tecnologias. Revista Brasileira de Docência, Ensino e Pesquisa em Educação Física, v. 1, n. 1, p. 53-75, ago. 2009.

DIEESE, Departamento Intersindical de Estatística e Estudos Socioeconômicos. O emprego doméstico no Brasil. Estudos e Pesquisas, n. 68, ago. 2013.

FAIRCLOUGH, N. Discurso e mudança social. Coordenação, tradução, revisão técnica e prefácio de Izabel Magalhães. Brasília: Universidade de Brasília, 2001.

GRACIA, T.I.. O “giro lingüístico”. In: IÑIGUEZ, L. (Coord.) Manual de análise do discurso em Ciências Sociais. Tradução de Vera Lúcia Joscelyne. Petrópolis: Vozes, 2004.

HALBWACHS, M. A memória coletiva. São Paulo: Vértice/Revista dos Tribunais, 1990.

HALL, S. A identidade cultural na pós-modernidade. Tradução de Tomaz Tadeu da Silva e Guaracira Lopes Louro. 3. ed. Rio de Janeiro: DP\&A, 1999.

$1 \quad$ As idades das depoentes têm por base o ano de 2014.

$$
\frac{\text { Comunicação \& Inovação, PPGCOM/USCS }}{\text { v. 16, n. } 30 \text { (55-74) jan-abr } 2015} 73
$$


IÑIGUEZ, L. (Coord.). Manual de análise do discurso em Ciências Sociais. Tradução de Vera Lúcia Joscelyne. Petrópolis: Vozes, 2004.

LE GOFF, J. Memória. In: ROMANO, Ruggiero (Dir.). Enciclopédia Enaudi. Porto: Imprensa Nacional/ Casa da Moeda, v. 1, p. 11-50, 1984.

MAINGUENEAU, D. Análise de textos de comunicação. Tradução de Cecília P. de Souza-e-Silva e Décio Rocha. São Paulo: Cortez, 2001.

. Termos-chave da Análise do Discurso. Tradução de Márcio V. Barbosa e Maria Emília A. T. Lima. Belo Horizonte: UFMG, 2000.

ORLANDI, E. Discurso e leitura. 6. ed. São Paulo: Cortez; Campinas: Universidade Estadual de Campinas, 2001. (Coleção passando a limpo).

PEREIRA, B. de P. De escravas a empregadas domésticas: a dimensão social e o "lugar" das mulheres negras no pós-abolição. Anais eletrônicos do XXVI Simpósio Nacional de História. ANPUH: 50 anos. São Paulo, 12 a 22 de julho de 2011. Disponível em: <www.snh2011.anpuh.org>. Acesso em: mar. 2014.

PINTO, M. J. Comunicação e discurso: introdução à análise de discursos. São Paulo: Hacker, 1999.

POLLAK, M. Memória e identidade social. Estudos Históricos, v. 5, n. 10. Rio de Janeiro, 1992.

THOMPSON, P. História oral: patrimônio do passado e espírito do futuro. In: WORCMAN, K.; PEREIRA, J. V. (Coord.). História falada: memória, rede e mudança social. São Paulo: SESCSP; Museu da Pessoa; Imprensa Oficial do Estado de são Paulo, 2006.

A voz do passado: história oral. 3. ed. São Paulo: Editora Paz e Terra, 2002.

WORCMAN, K.; PEREIRA, J. V. (Coord.). História falada: memória, rede e mudança sócia. São Paulo: SESCSP: Museu da Pessoa: Imprensa Oficial do Estado de São Paulo, 2006. 